\section{Use of Janus kinase inhibitors in COVID-19: a prospective observational series in 522 individuals}

Janus kinase (JAK) inhibitors for the treatment of hospitalised patients with COVID-19 have been extensively studied. Initially, at the start of the pandemic outside of China, baricitinib was shown using artificial intelligence to have a potential dual anticytokine and antiviral effect, computer predictions that were then supported by mechanistic data. ${ }^{1-3}$ This included kinase assays demonstrating inhibition of host numb-associated kinases, notably AP-2-associated protein kinase 1 (AAK1) and cyclin G-associated kinase (GAK), responsible for activating protein-1 (AP-1)-mediated viral propagation and super-resolution microscopy which showed inhibition of SARS-CoV-2 entry into primary human liver spheroids. ${ }^{4}$ Based on double-blind randomised data from the Adaptive COVID-19 Treatment Trial-II (ACTT-II) under the National Institutes of Allergy and Infectious Diseases, ${ }^{5}$ it received an Emergency Use Authorisation from the United States Food and Drug Administration in November 2020, in combination with remdesevir for the treatment of hospitalised individuals with COVID-19.

We implemented an institutional review board approved multicentre observational cohort study in four hospitals in Moscow, Russia, to both administer and collect clinical data on individuals treated with this class of drug. Data were prospectively obtained, focusing on the primary outcome of death. Secondary variables include duration of hospitalisation, severity of COVID-19 at admission, severity of pneumonia at imaging (CT0-CT4), requirement for mechanical ventilation, intensive care unit admission, thrombotic events, pulmonary emboli and secondary infectious complications. A total of 522 individuals between May and September 2020 were treated with either baricitinib or tofactinib, orally for 7-14 days. All the patients were hospitalised COVID-19 cases. Individuals with rheumatic or inflammatory bowel disease treated with JAK inhibitors were excluded.

All patients hospitalised from May to September 2020 were analysed for the purposes of the study. In those individuals treated with tofacitinib $(\mathrm{n}=320: 10 \mathrm{mg} \mathrm{n}=44 ; 20 \mathrm{mg}$ $\mathrm{n}=276), 293$ patients $(91.6 \%)$ recovered, and $27(8.4 \%)$ died. The mortality rate was $2.4 \%$ in patients younger than 65 years $(5 / 210$ patients) and $20 \%$ in patients of 65 years and older (22/110 patients), as shown in table 1 . In those who received baricitinib $(\mathrm{n}=202: 4 \mathrm{mg} \mathrm{n}=52,8 \mathrm{mg} \mathrm{n}=150)$, 193 patients $(95.5 \%)$ recovered, and $9(4.5 \%)$ died. The mortality rate measured $2.1 \%$ in patients younger than 65 years $(3 / 146)$ and $10.7 \%$ in patients of 65 years and older $(6 / 56)$ (table 2). With regards to imbalance in dexamethasone
Table 1 Clinical outcomes in patients with COVID-19 treated with tofacitinib

\begin{tabular}{|c|c|c|c|}
\hline & All cases & $<65$ years old & $\geq 65$ years old \\
\hline \multicolumn{4}{|l|}{ Population } \\
\hline Number of patents, $\mathrm{n}(\%)$ & $320(100)$ & $210(66)$ & $110(34)$ \\
\hline Female, $\%$ & 50 & 46 & 57 \\
\hline Mean age (range), years & $59(22-96)$ & $52(22-64)$ & $74(65-96)$ \\
\hline $\begin{array}{l}\text { Mean treatment duration } \\
\text { (range), days }\end{array}$ & $7(1-18)$ & $6(1-17)$ & $7(1-18)$ \\
\hline Dexamethasone, \% & 30.0 & 30.0 & 30.0 \\
\hline \multicolumn{4}{|l|}{ Disease (on admission) } \\
\hline \multicolumn{4}{|l|}{ Clinical severity, \% } \\
\hline Mild & 4.7 & 3.8 & 6.4 \\
\hline Moderate & 79.7 & 83.3 & 72.7 \\
\hline Severe & 15.0 & 11.9 & 20.9 \\
\hline Critical & 0.6 & 1.0 & 0.0 \\
\hline \multicolumn{4}{|l|}{ Lung involvement, \% } \\
\hline СТ 0 & 0.0 & 0.0 & 0.0 \\
\hline CT 1 & 10.9 & 10.0 & 12.7 \\
\hline $\mathrm{CT} 2$ & 65.0 & 68.6 & 58.2 \\
\hline CT 3 & 22.8 & 20.0 & 28.2 \\
\hline $\mathrm{CT} 4$ & 1.3 & 1.4 & 0.9 \\
\hline $\begin{array}{l}\text { C reactive protein: clinically } \\
\text { significant abnormality, } \%\end{array}$ & 73 & 74 & 71 \\
\hline \multicolumn{4}{|l|}{ Outcomes } \\
\hline Death, $n(\%)$ & $27(8.4)$ & $5(2.4)$ & $22(20.0)$ \\
\hline $\begin{array}{l}\text { Mean days from } \\
\text { hospitalisation till death } \\
\text { (range), days }\end{array}$ & $13(4-60)$ & $17(9-34)$ & $12(0-33)$ \\
\hline ICU admission, $\mathrm{n}(\%)$ & $65(20)$ & $28(13)$ & $37(34)$ \\
\hline $\begin{array}{l}\text { Mean stay in ICU (range), } \\
\text { days }\end{array}$ & $7(1-28)$ & $7(1-28)$ & $7(1-24)$ \\
\hline Mechanical ventilation, $\mathrm{n}(\%)$ & $28(8.8)$ & $11(5.2)$ & $17(15.5)$ \\
\hline $\begin{array}{l}\text { Mean duration of mechanical } \\
\text { vent. (range), days }\end{array}$ & $5(1-26)$ & $9(1-26)$ & $3(1-6)$ \\
\hline \multicolumn{4}{|l|}{ Safety } \\
\hline Thromboses, n (\%) & $7(2.2)$ & $2(1.0)$ & $5(4.6)$ \\
\hline Pulmonary embolism, n (\%) & $3(0.9)$ & $0(0.0)$ & $3(2.7)$ \\
\hline $\begin{array}{l}\text { Infectious complications, } \\
\mathrm{n}(\%)\end{array}$ & $22(6.9)$ & $9(4.3)$ & $13(11.8)$ \\
\hline
\end{tabular}

treatment, we may suppose that baricitinib was administered to patients with less severe disease (98\% mild and moderate) than tofacitinib $(84 \%)$. No tests was applied to evaluate the statistical significance of difference for 'COVID-19 severity' and 'lung involvement' because to compare baricitinib and tofacitinib treatments was not the objective of the study.

In general, we observed that JAK inhibitors were well tolerated with a low rate of complications. Clot risk during infection with SARS-CoV-2 is well described and mechanisms include activation of platelet-associated genes. ${ }^{4}$ Concerns regarding a prothrombotic tendency based on these data and previous studies ${ }^{5}$ appear unfounded in the context of SARS-CoV-2 infection, despite some concerns from previous trials in rheumatoid arthritis; real-world data outside the setting of COVID-19 have not suggested an increased clot incidence. ${ }^{6}$ As these data are not randomised and lack a comparator arm, we cannot draw conclusions regarding the efficacy of these drugs, but their oral use, lack of drugdrug interactions, short half-life with excretion via the renal system largely unchanged and dosing flexibility supports the use of these medicines in resource constrained or out-patient settings. As recently highlighted, ${ }^{7}$ drugs such as baricitinib appear to fulfil an unmet clinical need in the treatment of 


\begin{tabular}{|c|c|c|c|}
\hline & All cases & $<65$ years old & $\geq 65$ years old \\
\hline \multicolumn{4}{|l|}{ Population } \\
\hline Number of patents & 202 & 146 & 56 \\
\hline Female, $\%$ & 48 & 47 & 52 \\
\hline Mean age (range), years & $58(25-92)$ & $52(25-64)$ & $75(65-92)$ \\
\hline $\begin{array}{l}\text { Mean treatment duration } \\
\text { (range), days }\end{array}$ & $6(1-35)$ & $6(1-11)$ & $7(1-35)$ \\
\hline Dexamethasone, $\%$ & 7.4 & 7.5 & 7.1 \\
\hline \multicolumn{4}{|c|}{ Disease (on admission) } \\
\hline \multicolumn{4}{|l|}{ Clinical severity, \% } \\
\hline Mild & 3.0 & 3.4 & 1.8 \\
\hline Moderate & 95.0 & 95.2 & 94.6 \\
\hline Severe & 2.0 & 1.4 & 3.6 \\
\hline Critical & 0 & 1.0 & 0 \\
\hline \multicolumn{4}{|l|}{ Lung involvement, \% } \\
\hline СТ 0 & 0 & 0 & 0 \\
\hline CT 1 & 8.0 & 7.5 & 19.0 \\
\hline CT 2 & 71.2 & 68.5 & 78.5 \\
\hline CT 3 & 20.8 & 24.0 & 12.5 \\
\hline CT 4 & 0 & 0 & 0 \\
\hline $\begin{array}{l}\text { C reactive protein: } \\
\text { clinically significant } \\
\text { abnormality, \% }\end{array}$ & 95 & 92 & 100 \\
\hline \multicolumn{4}{|l|}{ Outcomes } \\
\hline Death, n (\%) & $9(4.5)$ & $3(2.1)$ & $6(10.7)$ \\
\hline $\begin{array}{l}\text { Mean from } \\
\text { hospitalisation till death } \\
\text { (range), days }\end{array}$ & $12(2-32)$ & $14(2-32)$ & $12(5-20)$ \\
\hline ICU admission, $\mathrm{n}(\%)$ & $19(9.4)$ & $10(6.9)$ & $9(16.1)$ \\
\hline $\begin{array}{l}\text { Mean stay in ICU (range), } \\
\text { days }\end{array}$ & $7(1-30)$ & $9(1-30)$ & $5(1-13)$ \\
\hline $\begin{array}{l}\text { Mechanical ventilation, } \\
\mathrm{n}(\%)\end{array}$ & $8(4.0)$ & $4(2.8)$ & $4(7.1)$ \\
\hline $\begin{array}{l}\text { Mean duration of } \\
\text { mechanical vent. (range), } \\
\text { days }\end{array}$ & $7(2-22)$ & $9(3-22)$ & $6(2-13)$ \\
\hline \multicolumn{4}{|l|}{ Safety } \\
\hline Thromboses, n (\%) & $1(0.5)$ & $0(0)$ & $1(1.8)$ \\
\hline $\begin{array}{l}\text { Pulmonary embolism, } \\
\mathrm{n}(\%)\end{array}$ & $1(0.5)$ & $0(0)$ & $1(1.8)$ \\
\hline $\begin{array}{l}\text { Infectious complications, } \\
\mathrm{n}(\%)\end{array}$ & $7(3.5)$ & $4(2.8)$ & $3(5.4)$ \\
\hline
\end{tabular}

$\mathrm{ICU}$, intensive care unit.

COVID-19 pneumonia. Ongoing studies such as ACTT-IV will help delineate its role versus dexamethasone.

Oleg Melikhov $\odot,{ }^{1}$ Tatiana Kruglova, ${ }^{2}$ Karine Lytkina, ${ }^{3}$

Georgy Melkonyan, ${ }^{3}$ Elena Prokhorovich, ${ }^{4}$ Gleb Putsman, ${ }^{5}$

Grigory Rodoman, ${ }^{5}$ Arkady Vertkin, ${ }^{4}$ Alena Zagrebneva, ${ }^{2}$ Justin Stebbing ${ }^{6}$

1 Institute of Clinical Research, Moscow, Russian Federation

${ }^{2}$ City Clinical Hospital No 52, Moscow, Russian Federation

${ }^{3}$ City Clinical Hospital No 4, Moscow, Russian Federation

${ }^{4}$ Moscow State University of Medicine and Dentistry n.a. Al Yevdokimov, Moscow, Russian Federation

${ }^{5}$ City Clinical Hospital No 24, Moscow, Russian Federation

${ }^{6}$ Imperial College London, London, UK

Correspondence to Dr Oleg Melikhov, Institut kliniceskih issledovanij 000,

Moskva 119590, Russian Federation; melikhov.oleg@gmail.com

Handling editor Josef S Smolen

Acknowledgements We acknowledge the kind help of Ekaterina Makarova and Svetlana Elkonina.
Contributors All authors contributed to writing the manuscript and approved the final version. $\mathrm{OM}$ and $\mathrm{AZ}$ contributed to conceptualisation, methodology, formal analysis, providing the resources, funding acquisition and project administration (responsible for overall content-guarantor). KL, TK, EP, GM, GP, GR, AV and JS contributed to data collection and analysis.

Funding Pfizer provided financial support for study design. Grant ID\#61 448843. The decision to submit the article for publication was made by the authors.

Competing interests JS conflicts are disclosed here: https://www.nature.com/ond editors.

\section{Patient consent for publication Not required.}

Ethics approval The study was approved on 19 June 2020 by Independent Interdisciplinary Ethics Committee (Leningrandsky prosp., 51, Moscow, 125468, Russian Federation).

Provenance and peer review Not commissioned; externally peer reviewed.

Supplemental material This content has been supplied by the author(s). It has not been vetted by BMJ Publishing Group Limited (BMJ) and may not have been peer-reviewed. Any opinions or recommendations discussed are solely those of the author(s) and are not endorsed by BMJ. BMJ disclaims all liability and responsibility arising from any reliance placed on the content. Where the content includes any translated material, BMJ does not warrant the accuracy and reliability of the translations (including but not limited to local regulations, clinical guidelines, terminology, drug names and drug dosages), and is not responsible for any error and/or omissions arising from translation and adaptation or otherwise.

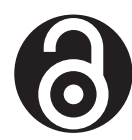

\section{OPEN ACCESS}

Open access This is an open access article distributed in accordance with the Creative Commons Attribution Non Commercial (CC BY-NC 4.0) license, which permits others to distribute, remix, adapt, build upon this work non-commercially, and license their derivative works on different terms, provided the original work is properly cited, appropriate credit is given, any changes made indicated, and the use is non-commercial. See: http://creativecommons.org/licenses/by-nc/4.0/.

(C) Author(s) (or their employer(s)) 2021. Re-use permitted under CC BY-NC. No commercial re-use. See rights and permissions. Published by BMJ.

- Additional supplemental material is published online only. To view, please visit the journal online (http://dx.doi.org/10.1136/annrheumdis-2021-220049).

\section{Check for updates}

To cite Melikhov 0, Kruglova T, Lytkina K, et al. Ann Rheum Dis 2021;80:1245-1246.

Received 1 February 2021

Accepted 25 May 2021

Published Online First 7 June 2021

Ann Rheum Dis 2021;80:1245-1246. doi:10.1136/annrheumdis-2021-220049

\section{ORCID iD}

Oleg Melikhov http://orcid.org/0000-0001-9442-7707

\section{REFERENCES}

1 Richardson P, Griffin I, Tucker C, et al. Baricitinib as potential treatment for 2019-nCoV acute respiratory disease. Lancet 2020;395:e30-1.

2 Stebbing J, Phelan A, Griffin I, et al. COVID-19: combining antiviral and antiinflammatory treatments. Lancet Infect Dis 2020;20:400-2.

3 Stebbing J, Krishnan V, de Bono S, et al. Mechanism of baricitinib supports artificial intelligence-predicted testing in COVID-19 patients. EMBO Mol Med 2020;12:e12697.

4 Stebbing J, Sánchez Nievas G, Falcone M, et al. Jak inhibition reduces SARS-CoV-2 liver infectivity and modulates inflammatory responses to reduce morbidity and mortality. SciAdv 2021;7:eabe4724.

5 Kalil AC, Patterson TF, Mehta AK. Baricitinib plus remdesevir for hospitalized patients with COVID-19. N Engl J Med 2020;4:795-807.

6 Peng L, Xiao K, Ottaviani S, et al. A real-world disproportionality analysis of FDA adverse event reporting system (FAERS) events for baricitinib. Expert Opin Drug Saf 2020;19:1505-11.

7 Goletti D, Cantini F. Baricitinib therapy in COVID-19 Pneumonia - an unmet need fulfilled. N Engl J Med 2021;384:867-9. 